\title{
1MDB corruption scandal in Malaysia: a study of failings in control and accountability
}

David Seth Jones

\begin{abstract}
Purpose - The aim of the paper is to examine the various aspects of the 1MDB scandal including the extent and types of corruption that occurred and the action taken to deal with them. In doing this, the paper seeks to identify the reasons for the scandal and the lessons that can be learnt to avoid such a scandal in Malaysia and elsewhere in the future.

Design/methodology/approach - The research for the paper is based on evidence from court hearings, reports of watchdog and regulatory agencies, media reports, and various articles and books written about $1 \mathrm{MDB}$.

Findings - The paper shows that most of the scandal involved embezzlement, bribery, false declarations and bond mispricing relating to extensive borrowing by $1 \mathrm{MDB}$, and entailed a global network of shell companies and individuals through which the illicit money was passed. It also shows weak governance in 1MDB, poor internal controls within banks, the failure of watchdog and enforcement bodies to take the necessary action partly due to political control over them, and overall the lack of political will to deal with the scandal.

Originality/value - The paper builds on the findings of other papers and books written on the 1MDB scandal. It does this by linking the corruption to the borrowings of $1 \mathrm{MDB}$, the international network of moneylaundering and bribery through which illicit money flowed, and the poor internal controls in the organisation. It also builds on previous research by highlighting the failure of banks to identify money-laundering and of watchdog and enforcement bodies to deal with the corruption. A further value of the paper is to identify the lessons that can be learnt about combatting corruption on such a scale.
\end{abstract}

Keywords Malaysia, Embezzlement, Bribery, Money-laundering, Mispricing, Shell companies

Paper type Research paper

\section{Introduction}

The 1 Malaysia Development Fund Bhd (1MDB) scandal is perhaps the most serious corruption scandal that has been recorded. The corruption has involved the embezzlement and laundering of billions of US dollars from its accounts together with gains from bribery and bond pricing, facilitated by false declarations by its officials and others. The illicit money was often transferred and laundered outside Malaysia. A cohort of bankers, businessmen and senior government officials mainly from Malaysia, but some from Saudi Arabia, the UAE and other countries have been implicated in the scandal. Increasingly from 2016 the spotlight has been placed on the former Malaysian Prime Minister, Najib Razak (who was also Chairman of the 1MDB Advisory Board), his wife, Rosmah Mansor, and Low Taek Jho (or Jho Low) a Malaysian businessman and associate of Najib. He is alleged to have been the mastermind behind the scandal.

The scandal came to light in 2015 and has given rise to investigations not only in Malaysia but in other countries where embezzled and other illicit money has been deposited and laundered. The investigations were intensified in 2018 with the change of government in

(C) David Seth Jones. Published in Public Administration and Policy. Published by Emerald Publishing Limited. This article is published under the Creative Commons Attribution (CC BY 4.0) license. Anyone may reproduce, distribute, translate and create derivative works of this article (for both commercial and non-commercial purposes), subject to full attribution to the original publication and authors. The full terms of this license may be seen at http://creativecommons.org/licences/by/4.0/legalcode

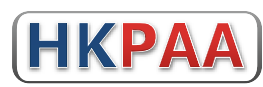

Received 6 November 2019 Revised 21 February 2020 Accepted 28 February 2020

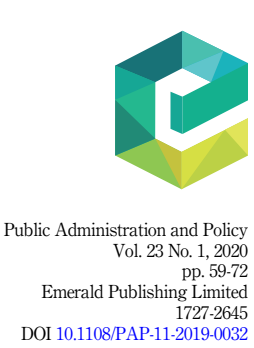


PAP

23,1

Malaysia when the Pakatan Harapan coalition, under the new Prime Minister Mahathir Mohamad, replaced the Barisan Nasional Government led by Najib, which had ruled Malaysia since independence in 1957. The investigations and court trials are still on-going, as more evidence of the scandal comes to light.

The paper examines the various corrupt practices in the 1MDB scandal and explains why they occurred, focusing on political control and the lack of proper surveillance and accountability, with consideration given to the lessons that can be learnt from the scandal.

\section{Aims, corporate structure and funding of $1 \mathrm{MDB}$}

1MDB began as the Terengganu Investment Authority (TIA), launched by the Menteri Besar (Chief Minister) of the State of Terengganu, Ahmad Said, in February 2009. It was set up as a holding and investment company for the State, and was funded initially by a bond issue of RM5 billion (US $\$ 1.19$ billion). In September 2009, it changed its status to a Malaysian national investment fund under the name of $1 \mathrm{MDB}$, wholly owned by the Malaysian Government through the Ministry of Finance Inc. (Ali, 2015, p. 134).

To facilitate its aims, 1MDB developed a network of joint ventures (JVs) with two subsidiaries of the Saudi Arabian company Petro Saudi International (PSI) and also an Abu Dhabi company, Aabar Investments PJSC, a subsidiary of the International Petroleum Investment Company (IPIC). From 2009 to 2015, 1MDB created numerous subsidiaries in its own right. Particular mention should be made of SRC International Sdn Bhd, whose remit was to borrow funds from the civil service pension fund, Kumpulan Wang Persaraan (KWAP). This company was separated from $1 \mathrm{MDB}$ in 2012 and became a wholly owned subsidiary of the Ministry of Finance Inc. (Auditor-General of Malaysia [AGM], 2016, pp. 57-62). As many of the JVs and subsidiaries of $1 \mathrm{MDB}$ were registered in other countries, it was difficult to trace illicit flows of money between them (Gabriel, 2018, pp. 69-70).

$1 \mathrm{MDB}$ had several sources of funding. The initial source was the funds of TIA, mainly derived from a conventional bond issue, transferred to $1 \mathrm{MDB}$ on its formation in 2009. The second source of funding was Islamic bonds or sukuk issues for a medium term in 2009, and a short-term note issued in 2014 (AGM, 2016, pp. 13-16, 237; US Department of Justice, [DOJ], 2019, p. 15). The third source of funding was three conventional bond issues in 2012 and 2013 which raised US $\$ 6.5$ billion from the local and international bond markets. Goldman Sachs played a central role in arranging and underwriting these bond issues, charging above the market rate of 7.7 per cent of the securities (Adam, 2018). Also relevant was the loan of RM4 billion (US $\$ 954$ million) provided by the Malaysian Government in 2011 from the country's civil service pension fund, and raised by the 1MDB subsidiary, SRC International (AGM, 2016, p. 214; Malaysiakini, 2016). This loan remains a key issue in the present trial of Najib. Together with other loans, the sum total of the borrowing by 1MDB in 2015 was RM41.9 billion (US $\$ 10$ billion) including RM8.2 billion (US $\$ 1.96$ billion) of inherited loans from companies it took over (AGM, 2016, p. 233; Boey, 2015).

\section{Corrupt practices \\ Embezzlement}

The main malpractice in the $1 \mathrm{MDB}$ scandal was embezzlement on an epic scale. It occurred in four phases and involved misappropriation of its funds largely derived from borrowing, through bond and sukuk issues and bank loans. The misappropriation involved six major embezzlements.

(1) During the Good Star phase (2009-2011), in 2009 US\$700 million (RM2.93 billion) of a cash grant of US $\$ 1$ billion (RM4.19 billion) by $1 \mathrm{MDB}$ to a JV with PSI, was siphoned 
off to be credited to an account of a company, Good Star Ltd, owned by Jho Low (Gabriel, 2018, p. 71; US DOJ, 2019, pp. 8, 17-18).

(2) In May 2011 an additional US $\$ 330$ million (RM1.38 billion) lent by 1MDB to the JV ended up as a deposit in the Good Star account (Lee, 2018; US DOJ, 2019, pp. 8-9, 17-18, 29-53).

(3) In 2012 during the Aabar-BVI phase, of US\$3.5 billion (RM14.51 billion) raised by $1 \mathrm{MDB}$ in bond issues in that year, approximately US $\$ 1.4$ billion (RM5.80 billion), was misappropriated, ending up in an account owned by Jho Low (Gabriel, 2018, p. 72; US DOJ, 2019, pp. 8-9, 53-88).

(4) In 2013 during the Tanore phase, more than US $\$ 1.26$ billion (RM5.30 billion) of a US $\$ 3$ billion (RM12.62 billion) bond issue was embezzled for the benefit of Low, his associates and officials in 1MDB (Gabriel, 2018, p. 72; Lee, 2018; US DOJ, 2019, pp. 9-10, 88-109).

(5) Also in 2013 some of the loans to SRC International from the civil service pension fund, mentioned above, were reportedly embezzled to the benefit of an associate of Jho Low, Eric Tan Kim Loong (Aw, 2016; Brown, 2018, p. 421). It is also alleged that some of the funds were diverted locally to the accounts of Najib and former Malaysian Treasury Secretary-General, Irwan Serigar (Ellis-Petersen, 2018).

(6) In 2014, US $\$ 850$ million (RM3.58 billion) were embezzled from a loan of US $\$ 1.23$ billion (RM5.15 billion) to 1MDB from a syndicate of banks. This loan was to be used as a cash payment to IPIC in return for which it would act as guarantor of $1 \mathrm{MDB}$ debt. Again the benefactors were Low and his associates (US DOJ, 2019, pp. 10, 54, 59,107-108; Wright and Hope, 2018, pp. 211, 216, 253).

Apart from being funneled through the chain of shell companies, the embezzled funds were also routed on occasions through the accounts of Low's father (a businessman) and brother. In addition, the nominal owner of some of the shell companies was Eric Tan, who acted as a proxy for Low. From these, large amounts of money were transferred to other accounts at the instruction of Low (Edge Malaysia, 2018a; Brown, 2018, p. 421; US DOJ, 2019, pp. 101, 232). According to US prosecutors, more than US $\$ 6.5$ billion (RM27.34 billion) flowed from 1MDB, "through a complex web of opaque transactions and fraudulent shell companies, to finance spending sprees by corrupt officials and their associates" (Tan, 2018). This plus the use of personal and family intermediaries and proxies were all designed to make it difficult to trace the final destination and ultimate use of the embezzled money.

\section{Bribery}

Bribery also figured in the 1MDB scandal. Bribes were offered by Goldman Sachs to and accepted by officials in $1 \mathrm{MDB}$ and the Malaysian Government to allow Goldman Sachs to arrange and underwrite the bond issues in 2012 and 2013 for a very high underwriting fee, as mentioned above. In a crucial piece of evidence, Goldman Sachs' chairman in Southeast Asia, Tim Leissner, pleaded guilty in a New York court in November 2018 and implicated others, stating:

While acting within the scope of my employment and with the intent to benefit Goldman Sachs and myself, as an employee and agent of Goldman Sachs, I entered into a conspiracy with those individuals identified in the Government's information to pay bribes and kickbacks to obtain and then retain business from 1MDB for Goldman Sachs. ... The goal of paying bribes and kickbacks was to influence the government officials to take official action so that Goldman Sachs would receive 
PAP

23,1

\section{2}

business from 1MDB. I took part in the process of paying some of these bribes and kickbacks (Edge Malaysia, 2018b).

Further bribes were offered to $1 \mathrm{MDB}$ officials in managing its accounts to facilitate the embezzlement, and also to key figures in the banks in which the embezzled money was deposited or through which it was transferred in order to ignore its illicit nature (eSpear, 2018).

\section{Money laundering}

Embezzlement and bribery in the $1 \mathrm{MDB}$ scandal led to another corrupt practice, namely, money laundering, which involved receiving or retaining money from these sources, disguising or not investigating its origins and purpose. Those in receipt either as intermediaries or ultimate beneficiaries were thus guilty of money laundering as was any bank (or legal or financial firm) which retained the money in one of its accounts on behalf of the sender or recipient without investigating its source. This was often in violation of antimoney laundering laws in the country to where such money was transferred, and in the case of banks, in breach of their own anti-money laundering compliance requirements.

Of course, given the chain of complex transactions through which the illicit money was transferred in the 1MDB scandal, the easier it was for recipients to cover up its origins and purpose, and the more difficult it was for the banks to undertake a proper investigation. As discussed below, the enforcement action against the corruption at 1MDB included money laundering as one of the key offences committed by both the recipients of the money and the banks involved in the retention and transfer of the money (Ramesh, 2016; eSpear, 2018).

\section{False declarations and bond mispricing}

Another aspect of the 1MDB scandal was the repeated false declarations made between 2009 and 2014, which were specified in the court hearings in the US. These included false declarations by $1 \mathrm{MDB}$ officials to banks in Malaysia responsible for forwarding embezzled money, and to overseas banks receiving the money. There were also false declarations by the recipients or intermediaries in the transfer of the money. One of them was Jho Low. False statements were made from time to time by senior officials of $1 \mathrm{MDB}$ to the IMDB Board, to the Bank Negara (Malaysian Central Bank) and to banks from which loans were acquired about the purpose of the loans and value of $1 \mathrm{MDB}$ assets offered as collateral (Ali, 2018, pp. 1869, 1883, 1898).

A further malpractice was the mispricing of the $1 \mathrm{MDB}$ bonds (setting of the interest rates well above the market rates for government-guaranteed debt) and their sale to chosen investors in a private placement. This may arguably be considered another form of corruption as the investors in the placement pool were able to reap rewards from subsequently selling the bonds (flipping) at a substantial profit because of the high interest rates attached to the bonds (KINIBIZ, 2015; Ali, 2018, pp. 1876, 1879).

\section{Cover-up and exposure of the scandal}

For a number of years the $1 \mathrm{MDB}$ scandal was covered up by the Malaysian Government. This was achieved in 2015 and 2016 by the removal from office of key officials including the Deputy Prime Minister, four other ministers, the Attorney-General and some lower level officials, who were otherwise prepared to unveil evidence of corruption or support an openended inquiry. The Government was also able to hide the scandal by ensuring that documents and computer files were withheld from investigators and auditors, and by influencing investigators in the National Audit Department and the Malaysian AntiCorruption Commission (MACC) to alter their findings or to abandon their investigations. 
This was illustrated not least in the redaction of the report of the AGM in 2016 (Latiff and Ananthalakshmi, 2018).

Despite the efforts of the Malaysian Government to cover up the scandal, evidence gradually came to light to show widespread irregularities. Firstly, anomalies in 1MDB were initially revealed in 2013 and came from two sources. One was the Malaysian on-line business newspaper KINIBIZ, which ran a series of articles on bond mispricing, overpayment for energy assets and other questionable deals (Gunasegaram and KINIBIZ, 2018, p. 14). The second was the web portal managed by British journalist Clare Rewcastle Brown, Sarawak Report, alleging that Goldman Sachs had been overpaid for the bond issues. The exposure then widened at the beginning of 2015, when a retired Swiss banker and ex-employee of PSI, Xavier Justo, forwarded to Brown thousands of documents, including 227,000 emails. They came from the servers of PSI, and unearthed evidence of the theft of hundreds of millions of dollars from 1MDB and other corrupt practices (Teh, 2018, pp. 187-191). Important sections of the evidence were published in the Sarawak Report, and from this source they were also published in the British Sunday Times and Guardian, and the Wall Street Journal.

This evidence was also reported a few months later in certain news outlets in Malaysia itself such as Utusan Malaysia, Malaysiakini, Malaysia Insider and various publications of the Edge Media Group (Teh, 2018, pp. 189-190). In addition, the local press provided from 2015 further information relating to the financial dealings of $1 \mathrm{MDB}$, together with major international newspapers including The Guardian, Daily Telegraph, and The Wall Street Journal. The press reports ensured that the scandal was kept at the centre of public attention. These reports gave opposition Members of Parliament (MPs) and some MPs of the ruling Barisan Nasional, important information to question the investment policies of $1 \mathrm{MDB}$ and raise suspicions of malpractices in its financial dealings. Ultimately, trust in Najib's government was undermined and contributed to its defeat in the 2018 general election. The concern of Najib's government regarding the role of the press was indicated in its suspension of two print publications of the Edge Media Group (the Edge Weekly and the Edge Financial News) in July 2015. The order was ruled as illegal and revoked three months later by the High Court.

The cover-ups indicated above have simply exacerbated the 1MDB scandal. As pointed out by Lowi (1988, pp. viii-ix), the repercussions of such cover-ups, which he refers to as the procedural scandal, may be as serious as the original malpractices, which he terms the substantive scandal (the actual embezzlement, money laundering, and bribery etc.). As the cover-ups have been exposed through the various channels mentioned above, so the procedural aspect of the scandal has increased alongside the substantive scandal.

\section{Investigation and enforcement \\ Malaysia}

Malaysia is of course the centre of the investigation into the corruption at $1 \mathrm{MDB}$. The new government under Mahathir took steps to revive the investigation, re-establishing the special task force. It comprises the MACC, Attorney-General's Chambers, Royal Malaysia Police, and Bank Negara Malaysia, and its leading members are those who figured in the original task force but who fell out of favour with the previous government. According to the office of Prime Minister Mahathir, "This special task force will be responsible on [sic] all aspects of the investigation, from financial tracking and asset acquisition which resulted from the mismanagement of $1 \mathrm{MDB}$ funds that are kept or invested in the country or abroad" (Star Online, 2018). Part of its remit is to cooperate with judicial and enforcement agencies in those countries which are also investigating the $1 \mathrm{MDB}$ scandal. The legislation under which enforcement is proceeding is the Anti-Money Laundering and Anti-Terrorism Financing Act, 
PAP

23,1

64

2001, the Malaysian Anti-Corruption Commission (Amendment) Act, 2018, and the Penal Code (Section 409).

\section{Other jurisdictions}

Given the international nature of the 1MDB scandal, investigations have been and continue to be conducted in a number of countries under their respective anti-corruption and anti-money laundering laws where financial institutions have been in receipt of illicit money from 1MDB. The focus has been largely on money laundering although other offences such as bribery and supplying dishonest and misleading information are being investigated. In Singapore, money laundering by certain banks and individuals connected to $1 \mathrm{MDB}$ has been investigated since 2016 and enforcement action taken, as mentioned below. Detailed investigation has also been conducted in Switzerland by the Money Laundering Reporting Office Switzerland (MROS), the Office of the Attorney General of Switzerland (OAGS), and the Swiss FINMA (Financial Market Supervisory Authority). The main focus of the investigation, as in Singapore, is money laundering given the large amount of embezzled money from 1MDB that passed through banks in Switzerland. The main legislation under which it is proceeding is the AntiMoney Laundering Act of 1997 (revised in 2009) (Attorney General of Switzerland, 2017, pp. 19-20). In addition, investigations into $1 \mathrm{MDB}$ corruption continue to be conducted in the USA where certain locally registered banks and their senior managers are currently being investigated for money laundering, bribery and other offences connected to 1MDB. The main anti-corruption agency involved in this task is the Money Laundering and Asset Recovery Section (MLARS) of the DOJ.

\section{Enforcement action so far}

In Malaysia charges have been levied against several 1MDB officials. The former CEO of 1MDB, Arul Kanda, was charged in December 2018 with tampering with the audit report on $1 \mathrm{MDB}$ in 2016 to eliminate evidence of corruption. But the centre of the investigation and the focus of media speculation is the role of former Prime Minister Najib. In 2018, he was charged with 21 counts of money laundering and four counts of abuse of power. The trial is now ongoing (Lim, 2019). So far, a key focus of the trial is his alleged involvement in the embezzlement of funds from the state pension fund through SRC. In addition, apart from the main individuals involved in the scandal, enforcement action is being taken against those persons who had illicitly received money from 1MDB. For example, on 7 October 2019, 80 persons were fined US\$100 million (RM418.6 million) for receiving illicit money from 1MDB (Associated Press, 2019).

In addition, in December 2018 the two leadings bankers of Goldman Sachs in Southeast Asia, Tim Leissner (Chairman) and Roger Ng Chong Hwa (Deputy Chairman), were charged with misappropriating US\$2.7 billion (RM11.34 billion), bribing officials and giving false statements when issuing the bonds (Makortoff, 2018). Most recently, 17 current and exexecutives of Goldman Sachs have been charged for their part, according to the Malaysian Attorney-General, in "the fraudulent misappropriation of billions in bond proceeds". The intention is to seek custodial sentences and criminal fines (Bowie and Mulberry, 2019).

In two other countries, banks and their senior employees have already been subject to sanctions. In Singapore four bankers from the Falcon Bank and Banca della Svizzera Italiana (BSI) were jailed for money laundering and related offences in 2016. The main charge was a failure to report suspicious and risky transactions as legally required with additional charges related to forging documents, mis-information and cheating. Four other bankers were given prohibition orders from 3 to 10 years for bribery and providing misleading information (Monetary Authority of Singapore [MAS], 2018, p. 11). Also in Singapore, fines of S\$31 million (US\$22.3 million) were imposed on the eight banks that received embezzled money from 
$1 \mathrm{MDB}$, for not paying due diligence to the source and purpose of the transactions in violation of the anti-money laundering regulations. Furthermore, two private Swiss banks, the Falcon Bank owned by IPIC, and BSI have been closed. The reason was the extent to which they laundered money embezzled from $1 \mathrm{MDB}$ funds, and the serious misconduct of their senior managers in dealing with 1MDB transactions (Daga, 2016; MAS, 2018, p. 11).

In Switzerland, three banks (Falcon, BSI and Coutts) have been fined a total of 103 million Swiss Francs (US\$105.2 million) for having "seriously breached money laundering regulations" in relation to the $1 \mathrm{MDB}$ scandal. Other banks which broke money laundering regulations in relation to $1 \mathrm{MDB}$ have not been fined, but informed by FINMA to improve their control and reporting procedures, followed by a period of close monitoring. FINMA has also warned the banks that if they do not improve their controls against money laundering, their licence to operate could be revoked. BSI, which has been the most culpable of the banks, has been taken over by another Swiss bank, EFG International. In addition, the OAGS is currently pursuing an investigation of six senior bank employees as a result of alleged personal gains from both the laundering of the embezzled money from 1MDB and accepting bribes to facilitate the money laundering (FINMA, 2017, pp. 18, 84; 2018, pp. 12, 16, 46, 72, 76).

Steps have been taken in the USA to impose sanctions on banks and individuals involved in money laundering and offering and taking bribes connected to 1MDB. Under the Kleptocracy Asset Recovery Initiative of the DOJ, complaints have been filed by the DOJ for the forfeiture and recovery of assets in the USA worth more than US $\$ 1.5$ billion paid for by the embezzled money and the bribes received. Sixteen senior figures in $1 \mathrm{MDB}$ and its JV partners, and their associates and cronies have been mentioned in US court files for involvement in the $1 \mathrm{MDB}$ scandal. In addition, in November 2018 indictments were issued in New York charging Low and his associate from Goldman Sachs, Roger Ng, for conspiring to launder billions of dollars embezzled from $1 \mathrm{MDB}$ and for paying bribes to various Malaysian and Abu Dhabi officials. Low is still at large while Ng is in remand in Malaysia and due to be extradited to the USA. Tim Leissner, as mentioned above, has already pleaded guilty in the USA to the charges of conspiring to launder money and paying bribes. According to court filings in the USA, he was ordered to forfeit US\$43.7 million (RM183.58 million) as a result of his money laundering and bribery and could be sentenced to a jail term of several years (US DOJ, 2018; New Straits Times, 2018).

In other countries, investigations of $1 \mathrm{MDB}$ are on-going with the likelihood of further charges being brought against those who were involved in the embezzlement, bribery and money laundering. These include Australia, New Zealand, Hong Kong, UAE and the United Kingdom. In these and other countries, banks, fund management companies, financial trusts and JV partners were located, which managed or guaranteed 1MDB assets, laundered the embezzled money or arranged 1MDB bond issues. In addition, in some of the countries involved in the scandal, the accounts of the shell companies were set up, in which the illicit money was deposited, or valuable physical assets were purchased from this money.

An important part of the enforcement work is the recovery of assets stolen from 1MDB and their return to Malaysia. So far, RM919 million (US\$218.6 million) has been recovered. In June 2019 it was announced that civil forfeiture action has been taken by the MACC to recover a further RM270 million (US\$64.3 million). Forfeiture claims are being made against 41 organisations and individuals. This is part of a long process to recover as much of the stolen funds as possible (Mackessey, 2019).

\section{Why did the 1MDB scandal arise?}

There are six reasons why the $1 \mathrm{MDB}$ scandal arose, as indicated below.

Firstly, the internal controls over spending, lending and investment in $1 \mathrm{MDB}$ were weak and reflected in a defective system of governance. This was highlighted by the AGM's report 
PAP

23,1

\section{6}

on $1 \mathrm{MDB}$ in 2016. It found that management practices were in contravention of the Companies Act of 1965, the Malaysian Code on Corporate Governance and international best practices on corporate governance. Many examples were given in the AGM's report, including key decisions made by a Written Board Resolution outside of a Board of Directors (BOD) meeting and not subject to the scrutiny of a Board meeting. The Board was also repeatedly fed false and inaccurate information. Some key financial and investment decisions were made without reference to or approval of the Board at all. Nor did the management and BOD undertake feasibility studies and a proper evaluation process where these were called for, reflected not least in the absence of an Investment Sub-committee of the BOD with a remit to examine both funding and investment risks for a particular project or debt issue (AGM, 2016, pp. 313-320). Moreover, the AGM's report found that the "maintenance of records and documents in $1 \mathrm{MDB}$ is not satisfactory" and were marked by "serious flaws". With such a lax system of control, it is not surprising that financial checks were not undertaken to identify and prevent the embezzlement of funds (AGM, 2016, p. 325; Ali, 2018, pp. 1867-1946 passim).

Secondly, the attempts to deal with corruption in $1 \mathrm{MDB}$ were hamstrung by political control over the watchdog and investigative agencies. The special task force formed in 2015 to uncover evidence of corruption, was soon after side-lined and then abandoned, after incriminating evidence against Najib emerged (Wright and Hope, 2018, pp. 139, 251-253). The Attorney-General was removed from office in 2015, MACC officers were harassed and arrested, and the Public Accounts Committee's investigation into 1MDB was disrupted (Ali, 2015, pp. 137-138). The AGM's own investigation in 2016 was shackled by a lack of access to $1 \mathrm{MDB}$ documents compounded by being prevented from accessing $1 \mathrm{MDB}$ computers and servers. The AGM's original report on $1 \mathrm{MDB}$ in 2016 was redacted where it contained damaging evidence relating to Najib, Low and others. Moreover, it was classified under the Official Secrets Act so it could not be read by MPs, the press, and the public and acted upon by the MACC and the Attorney-General (Ali, 2016, pp. 59-68; Aziz, 2018). The MACC's own investigations into $1 \mathrm{MDB}$ were also restricted. In 2015 it declared that the funds transferred from $1 \mathrm{MDB}$ to Najib's account, were not the result of embezzlement but were a donation from Saudi Arabia, with the investigating officials removed from office. The investigation was closed in 2017 (Wright and Hope, 2018, p. 249). In fact, Tunku Abdul Aziz Ibrahim, the advisory board chairman of MACC, reportedly stated in 2015 that the MACC had suffered from "meddling" by the Government that was "ill-advised" (Sherwell, 2015).

Thirdly, the corruption was facilitated by weak internal rules against money laundering in banks in Malaysia and elsewhere, and even where such rules existed by their willingness not to adhere to these rules or to anti-money laundering laws. It appears that given the profits to be made from managing such flows of money and the belief that little action would be taken against them, banks did not take money laundering prohibitions perhaps as seriously as they should have done. This again reflects how corruption springs from a perception that such practices were low risk and high reward (Gabriel, 2018, pp. 73-74; Fox, 2019). One commentary in 2019 singled out Goldman Sachs, stating: "the reality is that Goldman Sachs allowed key internal compliance controls to be over-ridden or simply avoided and there was no manner to check on what were clearly red flags raised". The commentary continued: "there was a culture which supported doing business even if it was done illegally and others consciously looked the other way" (Fox, 2019). These observations were supported by Tim Leissner's own testimony in his guilty plea (US DOJ, 2018).

According to its own assessment, Goldman Sachs acknowledged: “the firm's business culture, particularly in Southeast Asia, at times prioritized consummation of deals ahead of the proper operation of its compliance functions" (Goldman Sachs Group, 2018, p. 89). Although it pointed the blame specifically at its leading employees in Southeast Asia, Tim Leissner and Roger Ng, for "repeatedly lying to control personnel and internal committees", little seems to have been done to check the honesty of their reports (Goldman Sachs Group, 
2018, pp. 88-89). Much of this could have been said of other banks which were involved in raising loans for $1 \mathrm{MDB}$ and in handling illicit money transfers from embezzlement and bribery connected to $1 \mathrm{MDB}$.

The fourth and most important reason was the lack of political will. With Najib as Prime Minister and Chairman of 1MDB Advisory Board and allegedly himself a beneficiary of the embezzlement, there was no political will at the top to deal with the corruption in 1MDB. In fact, any minister in Najib's government who questioned the management of $1 \mathrm{MDB}$ was

removed from office and eventually expelled from the United Malays National Organisation (UMNO), the dominant party in the then ruling Barisan Nasional coalition. It was only after the change of government in May 2018, did the political will become evident to root out the corruption. This allowed the shackles to be lifted from the watchdog and investigative agencies and enabled a far reaching investigation to be conducted and enforcement action to be taken within Malaysia itself.

The fifth reason for the $1 \mathrm{MDB}$ scandal was the hegemonic nature of the democratic system in Malaysia until after the May 2018 general election. This was based on the continued dominance of the Barisan Nasional coalition, at the centre of which was the main political party UMNO. The Barisan Nasional in recent years used its hegemony to place constraints on watchdog and enforcement institutions, such as the MACC, the National Audit Department and the Police Force, whenever its interests were at stake, while preventing Parliament from effectively scrutinising and vetting the actions of the government. Under such hegemony, Prime Minister Najib was able to exercise his personal authority with little restraint to suit his own ends.

Finally, there existed a mind-set in high places in government and the private sector in Malaysia which considered corrupt practices leading to large financial gains as acceptable and to be engaged in when opportunities arose. This was also reflected in a previous major scandal involving the state bank, Bank Negara (Teh, 2018, pp. 24-29, 118-124). In recent years, corruption in Malaysia has deteriorated as its Corruption Perceptions Index (CPI) score has dropped from 52 in 2014 to 47 in 2018 (Transparency International, 2019). However, the defeat of the Barisan Nasional in the May 2018 general election resulted in Najib's arrest on 3 July by the new Pakatan Harapan government for money laundering and abuse of power. The change in government and the Pakatan Harapan government's strong anti-corruption stance is reflected in Malaysia's improved CPI score of 53 in 2019 (Transparency International, 2020).

\section{Consequences of the scandal}

Insolvency and bail outs

One consequence of the 1MDB scandal was to make the organisation insolvent by 2016, unable to meet key debt servicing payments. With so much money embezzled, the funds remaining for investment in many projects were insufficient to meet the interest payments on all of the borrowed funds. Subsequently, the Malaysian Government stepped in to pay RM6.98 billion (US $\$ 1.66$ billion) in debt servicing payments in 2016 and 2017. The payments were met from cash generated by the sale of land by the Malaysian central bank, Bank Negara, and by the issue of shares by the sovereign wealth fund of the Government of Malaysia, Khazanah Nasional Berhad (Tay, 2018; Aziz, 2018).

\section{Erosion of trust}

The second important consequence of the scandal was the erosion of public trust in both politicians and institutions of government. A survey of 1,000 persons in Malaysia conducted by civil society group Centre For a Better Tomorrow (Cenbet) in February 2018 
PAP

23,1

68

(before the general election), found that only 16 per cent expressed trust in Malaysian politicians and that only 29 per cent expressed trust in the Federal Government (Tho, 2018). It is likely that the emerging evidence of the $1 \mathrm{MDB}$ scandal had significantly decreased the level of trust, and in turn undermined support for Najib's government. The 1MDB scandal was a key issue in the campaign and certainly contributed to its defeat in the 2018 general election.

\section{Implications for combating corruption in Malaysia and other countries}

There are several implications of the $1 \mathrm{MDB}$ scandal which provide lessons for combating corruption in Malaysia and other countries.

Firstly, the 1MDB scandal indicates the necessity in public agencies engaged in major investment programmes, for strong internal auditing and management controls. Amongst other things, such controls can ensure that information presented to the Board of Directors with regard to the viability of investment projects, sources of funds, and disbursements of money is correct. They can ensure for bond issues with a government guarantee that underwriting fees and bond prices are close to market rates, and, where possible, private placements avoided. In this regard, action should be taken to identify if there has been bribery in setting the fees and bond prices and in the selection of investors in a private placement pool. In addition, control through a rigorous process of verification must be exercised on the remittances of money to outside bank accounts, and whether such remittances are intended to fund approved projects. Such controls can reduce the loopholes by which money is embezzled.

Secondly, it is essential that watchdog and investigative agencies in Malaysia such as the MACC, the National Audit Department, and the Attorney-General's Chambers should be protected from political interference. Such interference can only be prevented if there are safeguards both against pressure on such agencies to water down reports and remove evidence incriminating certain high level individuals in government, and also against restrictions on the availability of such reports to the public, the media and Parliament. Likewise, investigative and judicial staff should be protected against dismissal or harassment to stop them pursuing an investigation or engaging in a prosecution. This of course depends on the political will at the highest level of government to ensure such protection.

Thirdly, it is essential that banks in Malaysia and in other jurisdictions undertake thorough checks when transferring large amounts of money from a public agency to ensure that the remittance is for a legitimate purpose to fund an approved project. In addition, in the receiving banks, whether in Malaysia or overseas, due diligence should be exercised to identify the names of the recipient account holders and the true purpose for which the money was transferred so as to uncover money laundering. In this regard, internal compliance requirements in Malaysian banks and those in other jurisdictions regarding money laundering should be strengthened and strictly adhered to with the state financial services regulator or central bank (in the case of Malaysia, Bank Negara) monitoring adherence to both compliance standards and anti-money laundering laws.

Particular attention should be paid to accounts held by shell companies both on-shore and off-shore, to establish why, when, by whom and for what purpose such companies were registered, and to identify who are their owners. Where suspicions of money laundering arise such as when there are disproportionately large, frequent and unusual transactions involving shell companies, the accounts should be frozen or closed and information should be forwarded to the relevant anti-corruption agency and the financial services regulator or the central bank for further investigation. This is necessary given the leading role of shell companies in the transfer and laundering of embezzled money from 1MDB. It is noticeable 
that the MAS in Singapore has signalled to banks the need to be pro-active in detecting and reporting suspicious transactions by shell companies and to be prepared to close their accounts in order to combat money laundering. In fact, during the past twelve months under the guidance of the MAS, banks in Singapore have closed the accounts of several shell companies after detecting unlawful transactions (Daga, 2019). This is an example that could be followed in Malaysia.

Given the international nature of the $1 \mathrm{MDB}$ scandal, the prevention of illicit cross-border transfers of money, the penalties imposed on culpable banks and individuals, and the repatriation of stolen assets require much closer cross-border cooperation and more consistent application across jurisdictions. For example, a more consistent and stricter approach is required in dealing with shell companies (to follow Singapore's example), in applying guidelines in banks to check money laundering and in imposing penalties on culpable banks and their senior personnel that go beyond warnings and nominal fines.

In response to the 1MDB scandal the new Government unveiled in January 2019 a fiveyear plan to clamp down on corruption in government, called the National Anti-Corruption Plan (NACP) 2019-2023. The plan, launched by former Prime Minister Mahathir Mohamad himself, would entail major changes to the appointment process for key posts, require MPs and ministers to publicly declare their assets, and ensure new laws to regulate political funding and lobbying. This sounds promising and is intended to prevent another major corruption scandal, but it remains to be seen how vigorously the plan will be implemented in practice and whether it will be also affected by political influences (MACC, 2019).

\section{References}

Adam, S. (2018), "The 1MDB deals that continue to haunt Goldman Sachs", Bloomberg, New York, 17 December, available at: https://www.bloomberg.com/news/articles/2018-11-02/the-1mdb-dealsthat-continue-to-haunt-goldman-sachs-quicktake (accessed 12 February 2019).

Ali, A.M. (2015), "1MDB: the background", Journal of Public Administration and Governance, Vol. 5 No. 4, pp. 133-141.

Ali, A.M. (2016), "1MDB: the auditor general office's questions", Journal of Public Administration and Governance, Vol. 6 No. 1, pp. 50-72.

Ali, A.M. (2018), "1MDB: corporate governance going berserk? Part I", International Journal of Academic Research in Business and Social Sciences, Vol. 8 No. 12, pp. 1862-1946.

Associated Press (2019), "Malaysia fines 80 people, groups for alleged 1MDB payments", New York, 7 October, available at: https://www.usnews.com/news/business/articles/2019-10-07/malaysiafines-80-people-groups-for-alleged-1mdb-payments (accessed 12 October 2019).

Attorney General of Switzerland (2017), 2016 Annual Report of the Office of the Attorney-General of Switzerland, Office of the Attorney General of Switzerland, Berne.

Auditor-General of Malaysia (AGM) (2016), Report of the Auditor-General on 1MDB, National Audit Department, Putrajaya.

Aw, N. (2016), "The SRC phase - the unsolved piece in the 1MDB jigsaw", Malaysiakini, Petaling Jaya, 7 August, available at: https://www.malaysiakini.com/news/351404 (accessed 10 March 2019).

Aziz, A. (2018), "Malaysians deceived by 1MDB as it was govt that paid RM7b of its debts", Theedgemarkets.com, Petaling Jaya, 22 May, available at: http://www.theedgemarkets.com/ article/malaysians-deceived-1mdb-it-was-govt-paid-rm7b-its-debts (accessed 16 February 2019).

Boey, K.Y. (2015), "Malaysia banishes sukuk premium in US\$1.5bn issue", Reuters, London, 16 April, available at: https://www.reuters.com/article/asia-bonds-idUSL4N0XD36520150416 (accessed 8 May 2019).

Bowie, N. and Mulberry, M. (2019), "Goldman's 1MDB troubles grow deep and wide", Asia Times, Hong Kong, 14 August, available at: https://www.asiatimes.com/2019/08/article/goldmans1mdb-troubles-grow-deep-and-wide/ (accessed 17 August 2019). 

London.

Daga, A. (2019), "Singapore steps up scrutiny of shell firms to combat money laundering", Reuters, London, 12 August, available at: https://www.reuters.com/article/us-singapore-cenbank/ singapore-steps-up-scrutiny-of-shell-firms-to-combat-money-laundering-idUSKCN1V2231 (accessed 16 August 2019).

Edge Malaysia (2018a), "What role did mystery man Eric Tan play in the 1MDB scandal?" Petaling Jaya, 24 June, available at: https://www.theedgesingapore.com/what-role-did-mystery-man-erictan-play-1mdb-scandal (accessed 26 February 2019).

Edge Malaysia (2018b), "1MDB update: Leissner's court testimony in guilty plea”, Petaling Jaya, 28 November, available at: https:/www.theedgemarkets.com/article/1mdb-update-leissners-courttestimony-guilty-plea (accessed 24 March 2019).

Ellis-Petersen, H. (2018), "1MDB scandal: Najib Razak faces more charges over $\$ 1.6 \mathrm{bn}$ government coffer", The Guardian, London, 25 October, available at: https:/www.the-guardian.com/ world/2018/oct/25/1mdb-scandal-najib-razak-faces-more-charges-over-16bn-government-coffer (accessed 9 February 2019).

eSpear (2018), "Bribery and money laundering linked to 1MDB scandal", 24 July, available at: http://blog.espear.com/bribery-and-money-laundering-linked-to-1mdb-scandal/ (accessed 3 August 2019).

Financial Market Supervisory Authority (FINMA) (2017), Annual Report 2017, FINMA, Berne, available at: https:/www.finma.ch/en/documentation/finma-publications/annual-reports-andfinancial-statements (accessed 14 August 2019).

FINMA (2018), Annual Report 2018, FINMA, Berne, available at: https:/www.finma.ch/en/ documentation/ finma-publications/annual-reports-and-financial-statements (accessed 15 August 2019).

Fox, T. (2019), “1MDB: A guilty plea and two indictments”, JD Supra LLC, Sausalito, CA, 14 January, available at: https://www.jdsupra.com/legalnews/1mdb-a-guilty-plea-and-two-indictments34289/ (accessed 21 February 2019).

Gabriel, C. (2018), "The rise of kleptocracy: Malaysia's missing billions”, Journal of Democracy, Vol. 29 No. 1, pp. 69-74.

Goldman Sachs Group (2018), Quarterly Report Pursuant to Section 13 or 15(d) of the Securities Exchange Act of 1934 for the Quarterly Period Ended September 30, 2018, United States Securities and Exchange Commission, Washington DC, available at: https://www. goldmansachs.com/investor-relations/financials/current/10q/third-quarter-2018-10-q.pdf (accessed 5 May 2019).

Gunasegaram, P. and KINIBIZ (2018), 1MDB: The Scandal that Brought Down a Government, Strategic Information and Research Development Centre, Petaling Jaya.

KINIBIZ (2015), "How 1MDB lost RM6 bil through bond mispricing", Petaling Jaya, 16 December, available at: http://www.205395/how-1mdb-lost-rm6-bil-through-bond-mispricing.html (accessed 27 February 2019).

Latiff, R. and Ananthalakshmi, A. (2018), "The cover-up: Malaysian officials reveal just how much 1MDB probe was obstructed", Reuters, London, 4 July, available at: https://www.reuters.com/ article/us-malaysia-politics-najib-coverup-analy/the-cover-up-malaysian-officials-reveal-just-howmuch-1mdb-probe-was-obstructed-idUSKBN1JT2Z9 (accessed 9 October 2019).

Lee, L.H. (2018), “Stolen' 1MDB funds: the DOJ lawsuit revisited”, Malaysiakini, Petaling Jaya, 31 March, available at: https:/pages.malaysiakini.com/1mdb/en/ (accessed 9 February 2019).

Lim, I. (2019), "Najib's trial: Why it was postponed and how soon it can start", Malay Mail, Petaling Jaya, 19 February, available at: https://www.msn.com/en-sg/news/1mdb/najibs-trial-why-it-waspostponed-and-how-soon-it-can-start/ar-BBTMs1H?li=BBr8Cnr (accessed 12 March 2019).

Lowi, T. (1988), "Foreword" in Markovits, A.S. and Silverstein, M. (Eds), The Politics of Scandal: Power and Process in Liberal Democracies, Holmes and Meir, New York, pp. vii-xii. 
Mackessey, P. (2019), "Malaysia moves to recover \$65m stolen from Scandal-Hit state fund 1MDB", Anti-Corruption Digest, Paris, 24 June, available at: https://anticorruptiondigest.com/2019/06/24/ malaysia-moves-to-recover-65m-stolen-from-scandal-hit-state-fund-1mdb/\#axzz5wL7E9FQa (accessed 28 July 2019).

Makortoff, K. (2018), "1MDB scandal: Malaysia files charges against Goldman Sachs", The Guardian, London, 17 December, available at: https:/www.theguardian.com/world/ 2018/dec/17/1mdbscandal-malaysia-files-charges-against-goldman-sachs (accessed 8 May 2019).

Malaysiakini (2016), "What we know and don't know about the Najib cases”, Petaling Jaya, 26 January, available at: https://www.malaysiakini.com/news/328434 (accessed 4 October 2019).

Malaysian Anti-Corruption Commission (2019), "MACC news archive: National anti-corruption plan (NACP) 2019-2023", Putrajaya, 31 January, available at: https://www.sprm.gov.my/ index.php/en/arkib-berita-sprm/3227-national-anti-corruption-plan-2019-2023-nacp-2019-2023 (accessed 10 October 2019).

Monetary Authority of Singapore (MAS) (2018), Annual Report, 2017/18, MAS, Singapore.

New Straits Times (2018), "DOJ to charge former Goldman bankers, Jho Low over 1MDB scandal", Kuala Lumpur, 1 November, available at: https://www.nst.com.my/news/nation/2018/11/427365/ doj-charge-former-goldman-bankers-jho-low-over-1mdb-scandal (accessed 23 February 2019).

Ramesh, R. (2016), "1MDB: The inside story of the world's biggest financial scandal", The Guardian, London, 28 July, available at: www.theguardian.com/world/2016/jul/28/1mdbinside-story-worlds-biggest-financial-scandal-malaysia (accessed 24 February 2019).

Sherwell, P. (2015), "Top Malaysian anti-corruption official accuses government of 'meddling' in scandal investigation", Daily Telegraph, London, 4 September, available at: https://www. telegraph.co.uk/news/worldnews/asia/malaysia/11843195/Top-Malaysian-anti-corruption-officialaccuses-government-of-meddling-in-scandal-investigation.html (accessed 5 October 2019).

Star Online (2018), "Special task force formed to look into 1MDB", Petaling Jaya, 21 May, available at: https://www.thestar.com.my/news/nation/2018/05/21/special-task-force-formed-tolook-into-1mdb/ (accessed 15 February 2019).

Tan, A. (2018), "Singapore to expand 1MDB ciminal probe to include Goldman", Bloomberg, New York, 20 December, available at: https:/www.bloomberg.com/news/articles/2018-12-21/ singapore-said-to-expand-1mdb-criminal-probe-to-include-goldman (accessed 16 March 2019).

Tay, C. (2018), "MoF confirms former Govt bailed out 1MDB via BNM, Khazanah", Edge Malaysia, Petaling Jaya, 20 December, available at: http://www.theedgemarkets.com/article/mof-confirmsformer-govt-bailed-out-1mdb-bnm-khazanah (accessed 27 July 2019).

Teh, Y.K. (2018), From BMF to 1MDB: A Criminological and Sociological Discussion, Strategic Information and Research Development Centre, Petaling Jaya.

Tho, X.Y. (2018), "Armed forces the most trusted Malaysian institution, politicians the least, Cenbet survey finds", Star Online, Petaling Jaya, 5 July, available at: https://www.thestar.com.my/ news/ nation/2018/07/05/cenbet-survey-army-most-trustworthy (accessed 5 December 2019).

Transparency International (2019), "Malaysia - Corruption Perceptions Index", Berlin, available at: https://countryeconomy.com/government/corruption-perceptions-index/malaysia (accessed 5 October 2019).

Transparency International (2020), Corruption Perceptions Index 2019, Berlin.

US Department of Justice (2018), "News", Washington DC, 1 November, available at: https://www. justice.gov/usao-edny/pr/malaysian-financier-low-taek-jho-aka-jho-low-and-former-banker-ngchong-hwa-aka-roger (accessed 12 March 2019).

US Department of Justice (2019), “Case 2:19-cv-01327 Document 3”, Washington, DC, 22 February, available at: https://www.justice.gov/opa/press-release/file/1134381/download (accessed 18 April 2019).

Wright, T. and Hope, B. (2018), Billion Dollar Whale: The Man Who Fooled Wall Street, Hollywood, and the World, Hachette Books, New York, digital gallery edition. 
About the author

23,1

David Seth Jones was an Associate Professor at the Department of Political Science, National University of Singapore, and the Faculty of Business, Economics and Policy Studies, University of Brunei Darussalam. He is currently a Policy and Management Consultant specialising in government procurement, public finance, public management reform, and land policy. He has published widely in these fields. David Seth Jones can be contacted at: dsjones1x@gmail.com 